\title{
The Status of the Race Concept in Contemporary Biological Anthropology: A Review
}

\author{
Goran Štrkalj \\ School of Anatomical Sciences, University of the Witwatersrand, 7 York Road \\ 2198 Partktown, South Africa \\ Telephone: +27-11-717-2114, Fax: +27-11-717-2422, E-mail: Goran.Strkalj@wits.ac.za
}

KEYWORDS 'Race’. Human Variation. Biological Anthropology

\begin{abstract}
The race concept dominated the study of human biological variation for centuries. Prior to, and especially after, the Second World War, a number of anthropologists questioned the scientific value of the concept, initiating a debate over 'the existence of human races'. Research suggests that the debate has still not been resolved, as significant differences exist among anthropologists from different countries and regions of the world. In some places the concept of race seems to be falling out of favour (e.g., the USA and Western Europe), while in others it is generally accepted (e.g., China and Eastern Europe). The reasons for these differences are many and complex. They are of a scientific, ideological and professional nature. Furthermore, it would appear that chance, especially in smaller countries, plays a significant role in the attitudes of biological anthropologists towards the race concept.
\end{abstract}

\section{INTRODUCTION}

'Race', for centuries, was the core concept in the study of human biological variation. At the same time, 'race' has been the subject of some of the most intense debates in the history of anthropology, if not in science generally. Various aspects of 'race' have been discussed: the number of races, their origin, the value of the typological approach, possible racial superiority and many others. Even the age of the concept has been contested. Some argue that 'race' emerged relatively recently, in the 17 th century with the rise of modern science in Europe, and was deeply influenced by the social-political context of the time (e.g., Montagu, 1972; Fredrickson, 2001). Others claim that the concept was elaborated already in Antiquity (e.g., Snowden, 1983; Sarich and Miele, 2005).

Be that as it may, the debate on race acquired a new dimension in the mid-twentieth century when a number of anthropologists and biologists questioned the scientific value of the race concept and its applicability to the study of human variation. New approaches to the study of human variation, such as the clinal, which excluded the notion of race, were proposed. A debate ensued with a number of prominent scientists arguing for and against the concept of race (e.g., Dobzhansky, 1962; Garn, 1962; Montagu, 1964). This debate was particularly forceful in the early 1960s, shown by the number of articles published in the journal Current Anthropology (e.g.,
Livingstone, 1962; Dobzhansky, 1962; Newman, 1963; Brace, 1964). It would appear that the result of the great race polemic, which has included some of the most influential anthropologists and biologists, is still not clear. Although some authors explicitly state that the concept of race is dead in biological (physical) anthropology and that the debate about its value is over (Weiss and Fullerton, 2005), the empirical studies which investigated the status of the race concept in anthropology show that this is not the case. This paper will provide a brief review of these empirical studies (to which will be added some previously unpublished data) and will try to outline the main reasons behind biological anthropologists' attitudes towards 'race' and their current disagreements on the value of the concept.

\section{RACE CONCEPT IN DIFFERENT COUNTRIES AND REGIONS}

The first empirical research that tried to establish the status of the race concept among anthropologists appeared about thirty years ago (Lieberman and Reynolds, 1978). It was followed by a number of other studies, most of which were authored by Leonard Lieberman and his colleagues (anthropologists and sociologists) from the Central Michigan University (CMU) (e.g., Littlefield et al., 1982; Lieberman et al., 1989; Lieberman and Reynolds, 1996; Lieberman et al., 2003). Two basic methods were employed in these studies: survey, through a questionnaire 
distributed to working anthropologists (based on those listed in a guide compiled by the American Anthropological Association), and literature analysis (textbooks and research papers). These studies were, however, confined to anthropologists working in the USA and Canada, and textbooks and journals published in the USA. Research conducted by the CMU group, both the analyses of textbook contents and the surveys, suggested that among biological anthropologists 'race' was becoming increasingly rejected (Lieberman et al., 2003). Surveys conducted in 1984 and 1999 demonstrated this trend clearly. In both surveys, respondents were asked whether they agreed with the following statement "There are biological races within the species Homo sapiens." While in the first survey $50 \%$ of biological anthropologists answered 'yes', $41 \%$ 'no' and 10\% were neutral, in the second $24 \%$ answered 'yes', 69\% answered 'no' and $7 \%$ were neutral (Lieberman and Kirk, 2002).

The other line of research conducted by Cartmill (1998), however, seemed to contradict Lieberman's (2002: 102) suggestion that there was "a significant degree of change in the status of the race concept". Cartmill reviewed research papers published in one of the most influential publications in the field, the American Journal of Physical Anthropology, for the period 19651996. He endeavoured to establish whether authors had used the race concept in the research papers that focused on human variation. The study suggested that, although there were fluctuations from one year to the next, there was no trend towards the abandoning of the race concept. The author concluded that "the role played by racial taxonomy in the study of modern human variation has apparently changed little or not at all over the course of the past 30 years. In the 1990s, as in the 1960s, most researchers studying human variation do not make use of the concept of race in gathering and analyzing their data; however, a consistently large minority [40.5\%] continue to do so... [N] either the proponents nor the opponents of racial classification have any good reason to think that history is on their side" (Cartmill, 1998: 655-656).

More recently, a polemic developed between Cartmill and Lieberman (and their collaborators) concerning the apparently conflicting results of their studies (Cartmill and Brown, 2003; Lieberman et al., 2003). Although both authors noted possible biases in their adversaries' approaches, they agreed that differences in results may be due to the fact that they had focused on "different but overlapping populations" (Lieberman et al., 2003: 112). While Lieberman and collaborators had looked at the members of the American Anthropological Association (biological anthropologists irrespective of their field of research interest, including those who might not be active in research) Cartmill had looked at the biological anthropologists interested in human variation. More importantly, a substantial number of non-American anthropologists have published in the American Journal of Physical Anthropology. Thus, there was a distinct possibility that "the authors outside the United States are responsible for keeping the race concept alive in the pages of AJPA" (Cartmill and Brown, 2003: 115). It was, therefore, imperative to conduct similar surveys in other parts of the world.

If some early pilot studies using rather small sample sizes (Fuentes, 2000; Štrkalj, 2000a) are omitted it can be said that the first survey of anthropologists' attitudes towards the concept of race outside North America was conducted in Poland. In a survey of biological anthropologists (attendees of the annual meeting of the Polish Anthropological Society) respondents were asked, among other questions, whether they agree with the following statement "There are biological races (meaning subspecies) within the species Homo sapiens" (Kaszycka and Strzalko, 2002). The same question was used in similar American surveys as mentioned above, except that in this case the meaning of the term 'race' was specified. The results showed that $31 \%$ of respondents at the Polish meeting answered 'yes', 62\% 'no', and 7\% were neutral. It was hypothesised that the high number of 'yes' answers were due to the fact that race was identified with subspecies (Kaszycka and Štrkalj, 2002). In a follow up study conducted on the same population the same question was used. This time, however, the meaning of the term 'race' was not specified but interpreted in any of its possible meanings. The results (75\% 'yes', 25\% 'no') were significantly different (Kaszycka and Strzalko, 2003), corroborating the conclusion that in Poland "biological anthropologists have increasingly become inclined to abandon the concept of subspecies among living humans, while the concept of race by some other definition might still be accepted" (Kaszycka and Štrkalj, 2002: 334). 
Another relevant survey was conducted in China (Wang et al., 2002, 2003). This study followed Cartmill's approach and examined research papers published in China's leading journal in the field of biological anthropology, Acta Anthropologica Sinica (from 1982, when the journal was established, to 2002). It was found that all 324 papers dealing with human variation utilised the concept of race. This led to the conclusion that in Chinese biological anthropology the concept of race is deeply rooted (Wang et al., 2002, 2003).

Finally, a survey was completed on a large sample of European anthropologists. They were asked a number of questions including, as before, whether the scholars agreed with the statement on the existence of biological races among human species. The question was subdivided into one that identified the term race with subspecies and another that accepted 'race' broadly, by any of its possible meanings. The final results have not yet been published but preliminary analysis suggests one noteworthy pattern. It would appear that there is a significant difference between biological anthropologists from Western and Eastern Europe (ex-Soviet bloc). Generally, the majority of anthropologists reject the concept of race in the former, while the majority accept it in the latter (cf. Kaszycka et al., 2003; Lieberman et al., 2004)

\section{DISCUSSION}

It would appear that two conclusions strongly emerge from research on the status of the race concept in biological anthropology: there is still no consensus on the race concept and there are significant national/regional differences in anthropologists' attitudes towards 'race'. The reasons for these differences are manifold and of both a scientific and external nature. Indeed, complex scientific issues, such as those surrounding the concept of race, can be understood only if one looks at a variety of influencing factors.

Perhaps the first issue to bear in mind when analysing the status of the race concept is the complexity of human biological variation (Štrkalj, 2006). Humans are a globally dispersed species, numbering more than 6 billion individuals, with a complex evolutionary history mediated by culture. It is no surprise, therefore, that there are, among working scientists, marked differences in approaches, including that on the usefulness of the race concept. The complexity of biological reality therefore seems to induce differing positions on it. A similar phenomenon is noted by Eldredge (1993) concerning problems surrounding the concept of species. He noted that "biologists of varying perspectives indeed 'see' different sorts of species in biotic nature (and, epistemologically, even in the same data set) but do so, at least in part, not out of slavish adherence to a particular theoretical perspective but because biotic nature is indeed 'packaged' into discrete or quasi-discrete entities of different sorts" Eldredge (1993: 4).

Another possible reason behind the current differences concerning the race concept is the uncertainty about the meaning of the term 'race' (cf. Templeton, 1998; Strzalko, 2000b; Pearson, 2002; Kaszycka and Strzalko, 2003). Indeed, it has been argued several times in the history of anthropology that terminological change might significantly reduce misunderstandings concerning human variation (e.g. Huxley and Haddon, 1936; Montagu, 1951, 1964; Garn and Coon, 1955; Štrkalj, 2000b; Thompson, 2006). The two Polish studies discussed above clearly show how attitudes towards 'race' change dramatically with changes in the definition of the term.

It should also be added that biological anthropology is a relatively new discipline (Štrkalj, 2000c) and that it is to be expected that future theoretical insights and developments in empirical research might contribute towards a better understanding of human variation, infraspecific classifications and the race concept.

The status of the race concept cannot be comprehended fully if the broader social context is not taken into account. Historians and sociologists of science have shown how social factors influence science, the only question being how powerful this influence is. Many anthropologists involved in the study of human variation also emphasised the importance of these factors in their field of study. For example, in his textbook on human biodiversity, Marks (1995: 2) argues that "scientists' ideas are formed partly through what we like to imagine is the objective analysis of data; but also, like the ideas of anyone else, formed partly by their cultural upbringing and life experiences." This, he argues, is particularly important to acknowledge in disciplines that are involved in the study of human beings, such as anthropology. Following Lieberman (2001: 74), 
however, the author of the present paper does not take "the extreme deconstructionist view that scientific knowledge about socially sensitive subjects changes with changing social and cultural conditions and therefore can allow us only very limited glimpses into the realities of nature", preserving the belief "that knowledge can represent nature with increasingly greater accuracy when we are aware of our methodological errors, our accumulated knowledge, and the influence of our social and historical context."

Simplified somewhat, it could be stated that 'race' plays different roles and fulfils diverse expectations in different societies. Two multiethnic countries, the USA and China provide good examples. The USA is a country with a long history of racial problems. Historically 'racial science' in America, from Samuel George Morton to Carleton Stevens Coon, was often racist in nature and even contributed towards the implementation of segregationist policies (e.g., Barkan, 1992; Marks, 1995; Gossett, 1997; Jackson, 2001). In the words of Baker and Patterson (1994: 1) "the ideology of race has played a significant role in the development and professionalization of anthropology in the United States". Although American society endured radical changes through the process of desegregation, the consequences of its racist past are still felt. 'Race' is therefore a very sensitive and politically charged issue. Consequently, even belief in the existence of human races is often seen, especially in liberal academic circles (Sarich and Miele, 2005), as a potential contributor to social disturbance. In China, on the other hand, race seems to be a factor for social cohesion. A strong message that emanates from the research on human variation is that the ethnically diverse populations of China are unified by belonging to the same Mongoloid race (Wang et al., 2002, 2003). This seems to have been a leitmotif in studies of human variation in China throughout history and this racial identity is often traced back into the evolutionary past to the Chinese Homo erectus (Dikötter, 1992; Wang, 2002, 2003; Lieberman et al., 2004). Simplifying matters again, it may be stated that the racial approach is not a politically correct one in the USA. Anthropologists might therefore not feel at ease (to say the least) should they employ this approach, as they might be branded as racists. In stark contrast the racial approach is politically correct in China and scientists seem to be 'encouraged' to use the concept both in public and scientific discourse (Wang, 2003). Social context, therefore, plays a significant role in anthropologists' attitudes towards 'race' and in the significant differences between the scientists from these two countries.

Professional factors, too, seem to play an important role in scientists' racial attitudes. Historically, the non-racial approach towards the study of human variation is a Western (primarily American) phenomenon. It was conceived in the works of authors such as Ashley Montagu, Frank Livingstone and C. Loring Brace (e.g., Montagu, 1964). It would appear that these ideas did not, for various reasons (political, social, linguistic), permeate equally well and equally fast through all scientific communities. Relative isolation from the West might be the reason why the race concept has received better acceptance among anthropologists from Eastern Europe and China than among those from Western Europe and North America.

Finally, the role of "the vagaries of chance", in the words of science historian John Waller (2002: 8 ), in the scientific enterprise should not be forgotten. This factor might have played an important role in anthropologists' racial attitudes. Very few or even one working scientist, for example, may influence generations of students and junior collaborators. A single or small group of anthropologists who have been a leading force in a particular scientific community may overly influence that community if it is small. Indeed, it has been established in the Polish survey that in certain institutions the outlook of the majority of the members was formulated according to the views of the leading figure in that particular institution (Kaszycka and Štrkalj, 2002). It is possible that this might happen across a whole country, if small enough. As previously mentioned, the majority of anthropologists in Eastern European countries accept the race concept. However, one exception is Croatia. Because anthropological research is often expensive and in only rare cases produces economically feasible results, most of the research in small countries is carried out in a few institutions. In Croatia the majority of anthropologists work in one centre the Institute for Anthropological Research. The Institute's leading researchers in biological anthropology have had research experience at institutions in the developed English-speaking 
countries (Rudan et al., 2002). Therefore, it is very likely that these researchers were exposed to and possibly accepted the non-racial approach and that their ideas were passed on to other members of staff of the Institute. In larger countries such as Russia or Poland, the influence of one group of researchers would probably not have been felt so strongly.

Research shows that there is as yet no consensus on the status of the concept among biological anthropologists. It also suggests that the reasons (which we are only beginning to understand more fully) for differences in biological anthropologists' attitudes towards race are to be sought in a variety of scientific, social and professional factors as well as "the vagaries of chance". It is hoped that future research, especially empirical studies on the concept and its status (including surveys of previously unanalysed literature and scientific communities), might yet provide further insights into this complex and elusive subject.

\section{ACKNOWLEDGEMENTS}

I thank Professor Phillip V. Tobias, Mr David Chorn and two referees for their valuable comments.

\section{REFERENCES}

Baker, L.D. and Patterson, T.C.: Race, racism and the history of U.S. anthropology. Transforming Anthropology, 5: 1-7 (1994).

Barkan, E.: The Retreat of Scientific Racism: Changing Concepts of Race in Britain and the United States between the World Wars. Cambridge University Press, Cambridge (1992).

Brace, C.L.: On the concept of race. Curr. Anthropol., 5: 313-320 (1964).

Cartmill, M.: The status of the race concept in physical anthropology. Am. Anthropol., 100: 651-660 (1998).

Cartmill, M. and Brown K.: Surveying the race concept: a reply to Lieberman, Kirk and Littlefield. Am. Anthropol., 105: 114-115 (2003).

Dikötter, F.: Discourse on Race in Modern China. Stanford University Press, Stanford (1992).

Eldredge, N.: What, if anything, is a species?, pp. 3-20. In: Species, Species Concepts, and Primate Evolution. W.H. Kimbel and L. B. Martin (Eds.). Plenum Press, New York and London (1993).

Garn, S.: Human Races. $2^{\text {nd }}$ edn. C. C. Thomas, Springfield (1962).

Garn, S. and Coon, C.S.: On the number of races of mankind. Am. Anthropol., 57: 996-1001 (1955).

Gosset, T.F.: Race: The History of an Idea in America. New edn. Oxford University Press, New York and Oxford (1997).
Huxley, J.C. and Haddon, A.C.: We Europeans: A Survey of "Racial" Problems. Harper and Bros, New York (1936).

Jackson, J.P.: "In ways unacademical": the reception of Carleton S. Coon's The Origin of Races. J. Hist. Biol., 34: 247-85 (2001).

Kaszycka, K.A. and Štrkalj, G.: Anthropologists' attitudes towards the concept of race: the Polish sample. Curr. Anthropol., 43: 329-35 (2002).

Kaszycka K.A., Štrkalj, G. and Lieberman, L.: Is there still support for the race concept? The European pilot study. Book of Abstracts, 33 ${ }^{\text {rd }}$ Annual Conference of the Anatomical Society of Southern Africa (2003).

Kaszycka, K.A. and Strzalko, J.: 'Race' - still an issue for physical anthropology? Results of Polish studies seen in the light of the U.S. findings. Am. Anthropol., 105: 114-22 (2003).

Lieberman, L.: How "Caucasoids" got such big crania and why they shrank. Curr. Anthropol., 42: 69-95 (2001).

Lieberman, L., Fuentes, A.J.M, Kaszycka, K.A., Yablonski, L., Kirk, R.C., Štrkalj, G., Wang, Q. and Sun, L.: The race concept in five regions: variations without consensus. Collegium Antropol., 28: 907921 (2004).

Lieberman, L. and Kirk, R.C.: The 1999 status of the race concept in physical anthropology: two studies converge. Am. J. Phys. Anthropol., Suppl. 34: 102 (2002).

Lieberman L., Kirk, R.C. and Littlefield, A.: Perishing paradigm: race - 1931-99. Am. Anthropol., 105: 110-113 (2003).

Lieberman, L. and Reynolds, L.T.: The debate over race revisited: an empirical investigation. Phylon, 39: 333-343 (1978).

Lieberman, L. and Reynolds L.T.: Race: the deconstruction of a scientific concept, pp. 142-173. In: Race and Other Misadventures: Essays in Honor of Ashley Montagu in his Nineteenth Year. L.T. Reynolds and L. Lieberman (Eds.). General Hall, Dix Hills (1996).

Lieberman, L., Stevenson, B.W. and Reynolds, L.T.: Race and anthropology: a core concept without consensus. Anthropol. Educ. Quart., 20: 67-73 (1989).

Littlefield, A., Lieberman, L. and Reynolds, L.T.: Redefining race: the potential demise of a concept in physical anthropology. Curr. Anthropol., 23: 641655 (1982).

Livingstone, F.B.: On the non-existence of human races. Curr. Anthropol., 3: 279-281 (1962).

Marks, J.: Human Biodiversity: Genes, Race, and History. Aldine de Gruyter, New York (1995).

Marks, J.: Human biodiversity as a central theme of biological anthropology: then and now. Kroeber Anthropological Society Papers, 84: 1-10 (2000).

Montagu, A.: A consideration of the concept of race. Cold Spring Harb. Sym., 15: 315-336 (1951).

Montagu, A. (Ed.): The Concept of Race. Free Press, New York (1964).

Montagu, A.: Man's Most Dangerous Myth: The Fallacy of Race. Columbia University Press, New York (1972).

Newman, M.T.: Geographic and microgeographic races. Curr. Anthropol., 5: 189-207 (1963).

Pearson, R.: The debate on race: a problem of semantics rather than of biology Mankind Quart., 42: 419440 (2002). 
Rudan, P., Novokmet, N., Škaric-Juric, T., and Janovic, T.: Deset Godina Instituta za Antropologiju. Hrvatsko Antropološko Društvo i Institut za Antropologiju, Zagreb (2002).

Sarich, V. and Miele, F.: Race: The Reality of Human Difference. Westview Press, Boulder (2005).

Snowden, F. Jr.: Before Color Prejudice: The Ancient View of Blacks. Harvard University Press, Cambridge (1983).

Štrkalj, G.: Still no consensus on race? International Association of Human Biologists Newsletter, 30: 2832 (2000a).

Štrkalj, G.: Form and race: terminological concepts for the study of human variation. Mankind Quart., 41: 109-18 (2000b).

Štrkalj, G.: The conflict of pre-paradigm schools in modern human origins research. Acta Biotheor, 48: 65-71 (2000c).
Strkalj, G.: Artificial classification and the study of human variation. Riv. Biol. - Biol. Forum, 99: 14-20 (2006).

Templeton, A.: Human races: a genetic and evolutionary perspective. Am. Anthropol., 105: 632-650 (1998).

Thompson, E.C.: The problem of "race as a social construct". Anthropology News, 47(2): 6-7 (2006).

Waller, J.: Fabulous Science: Fact and Fiction in the History of Scientific Discovery. Oxford University Press, Oxford (2002).

Wang, Q., Strkalj G. and Sun L.: The status of the race concept in Chinese biological anthropology. Anthropologie, 40: 95-98 (2002).

Wang, Q., Štrkalj G. and Sun L.: On the concept of race in Chinese biological Anthropology: alive and well. Curr. Anthropol., 44: 403 (2003).

Weis, K.M. and Fullerton, S.M.: Racing around, getting nowhere. Evol. Anthropol., 14: 165-169 (2005). 